Kende Agnes ${ }^{1}$ - Messing Vera ${ }^{2}-$ Fejes József Balázs ${ }^{3}$

${ }^{1}$ Rosa Parks Alapítvány, CEU Democracy Institute

${ }^{2}$ Társadalomtudományi Kutatóközpont, CEU Democracy Institute

${ }^{3}$ Szegedi Tudományegyetem Neveléstudományi Intézet, Motiváció Oktatási Egyesület

\title{
Hátrányos helyzetü tanulók digitális oktatása a koronavírus okozta iskolabezárás idején
}

\author{
A koronavirus miatti iskolabezárások várhatóan tovább \\ növelik az oktatási egyenlótlenségeket. Munkánk célja a \\ hátrányos helyzetú és roma tanulókat oktató iskolák és \\ tanárok tapasztalatainak feltárása volt az iskolabezárások \\ elsó hónapjában, 2020 tavaszán.
}

A koronavírus terjedésének megakadályozása miatt 2020. március 16-ától a magyarországi általános és középiskolák digitális oktatásra tértek át. A tanulók nem látogathatták az iskolákat, a tanárok és diákok személyesen nem találkozhattak, a tanórákat az online térben kellett megtartani. Magyarországhoz hasonlóan a világ nagy részén is bezárták az iskolákat részlegesen vagy teljesen; összesen 1 milliárdnál több iskolásnak kellett otthonról tanulnia 2020 tavaszán (OECD, 2020). Az átállás mindenhol felkészületlenül érte az iskolákat és pedagógusokat, és nagyon gyors adaptációt igényelt az oktatás összes szereplője - iskolavezetés, pedagógusok, tanulók és családjuk és az oktatásirányítás - részéről. A magyar pedagógusok használhatták az iskolai infrastruktúrát, de az oktatást online módon kellett megszervezniük (EMMI, 2020). A digitális oktatás három teljes hónapon át, lényegében a tanév végéig (2020. június 15.) érvényben volt. A digitális oktatásra való áttérés vélhetően tovább növelte a legsebezhetőbb és ezen belül a legnehezebb társadalmi helyzetben élö gyermekek oktatási hátrányait, ugyanakkor ennek részleteiről nem rendelkezünk pontos információkkal, ami akadálya a hatékony válságkezelésnek.

Kutatásunk célja az volt, hogy feltérképezzük a koronavírus miatti iskolabezárás rövid távon is jelentkező következményeit az alacsony szocioökonómiai hátterü tanulók kapcsán a pedagógusok első tapasztalatai alapján 2020 tavaszán. A hátrányos helyzetü tanulókkal összefüggésben egyrészt arra voltunk kíváncsiak, hogy milyen akadályokat látnak a pedagógusok a digitális oktatásra való átállás kapcsán, másrészt arra, hogy a gyakorlatban milyen módon valósul meg a digitális oktatás. Elemzésünk alapjául egy online kérdőív szolgált, amelyet a digitális tanrendre való átállás első hónapját követően töltött ki 425 pedagógus. Adataink további forrását iskolaigazgatókkal, valamint roma és roma közösségeket segítő civilszervezetek vezetőivel készített interjúk jelentik. Írásunk hangsúlyossá tesz néhány olyan akut problémát, amelyeket a digitális átállás felerősített, ám amelyekkel a magyar oktatási rendszer hosszú idő óta küzd, úgymint az oktatási rendszer társadalmi egyenlőtlenségeket felerösítő sajátossága, a tanulás módszertanának elavultsága, vagy éppenséggel a kormányzati oktatásirányítás rugalmasságának hiánya. 


\section{Szakirodalmi áttekintés}

\section{Az elsö tapasztalatok}

A digitális oktatásra való átállásra mindössze egy hétvége állt rendelkezésére, ami - bármilyen felkészültek is legyenek - mindenképpen váratlan helyzet elé állította az oktatás összes szereplőjét: a pedagógusokat, a tanulókat és családjaikat és az oktatásirányítást is. Kutatásunk az átállást követő harmadik héten zajlott. Még a nemzetközi szakirodalom is kevés olyan kutatást tud felmutatni, amely ilyen rövid távon, empirikus bizonyítékokkal alátámasztva mutatja be a digitális átállás következményeit. E pontban az eddig rendelkezésre álló információk alapján foglaljuk össze az elérhető eredményeket, elsősorban a szocioökonómiai státuszból eredö különbségekre fókuszálva.

Grewenig és munkatársai (2020) szülői kérdőíven $(\mathrm{n}=1099)$ keresztül vizsgálták általános és középiskolás korú tanulók időhasználatai szokásait Németországban, a tanulókat a szülők véleménye alapján jól és rosszul teljesítők csoportjára osztva. Eredményeik szerint az órai részvételen kívül a tanulással töltött idő nagyjából a felére csökkent a roszszul teljesítők körében, és ezt az időt általában olyan, fejlődésüket nem segítő tevékenységekkel töltötték ki, mint tévénézés vagy számítógépes játékok. Bár a szülők iskolai végzettsége szerint nem találtak különbséget az időhasználati szokások változásában, a szülők iskolai végzettsége és gyermekeik iskolai sikeresség közötti összefüggés miatt az eredmények az oktatási egyenlőtlenségek erősödésére utalnak. Andrew és munkatársai (2020) ugyancsak szülőkkel $(n=5582)$ kitöltött kérdőív alapján vizsgálta az iskolabezárások következményeit az USA-ban. E felmérés az időhasználati szokások változásában eltéréseket jelzett a családok társadalmi helyzete szerint, ugyanakkor ez csak az általános iskolás korosztály körében mutatkozott meg. Emellett az eredmények szerint nemcsak az otthoni infokommunikációs (továbbiakban: IKT) eszközök és internetelérés terén mutatkozott észlelhető különbség a különböző szocioökonómiai státuszú családok között, de az alacsony státuszú családok számára kínált iskolai szolgáltatások is szegényesebbek voltak, kevésbé volt jellemző az aktív tanulástámogatás (pl. online órák), és gyakoribbak voltak a passzív megoldások (pl. feladatkiadás elérhető segítség nélkül).

Néhány kutatás a háztartásokat lakóhely alapján különböző jövedelmi csoportokba sorolva vizsgálta az online aktivitás különbségeit a tanulás kapcsán az iskolabezárások idején (pl. Bacher-Hicks és mtsai, 2020; Chetty és mtsai, 2020). E kutatások nem meglepő módón megerősítették a magasabb jövedelmi csoportba sorolt háztartások magasabb online aktivitását, ami a távoktatáshoz való jobb alkalmazkodás egyik jelének tekinthető.

McNulty és Baird (2020) több mint 1,6 millió 2-12. évfolyamos amerikai tanuló olvasási teljesítményének változását elemezte egy évente elvégzett adatfelvételhez kapcsolódva, így az iskolabezárások előtt és után elvégzett adatfelvétel eredményeit a tanulók szokásos (várható) fejlődésével is összehasonlíthatták. Elemzésük szerint az iskolabezárások alatt 18 százalékkal növekedett a teljesítménykülönbség a szocioökonómiai státusz szerinti kedvező és kedvezőtlen tanulói összetételü iskolák azon diákjai között, akik nem vettek rész aktívan a tanulásban. Adataik szerint a kevésbé fejlett olvasási képességgel rendelkező tanulók (alsó 25\%) kevésbé vettek részt az online oktatásban, és a jól olvasókhoz (felső 25\%) viszonyítva a teljesítménykülönbség további 6 százalékkel növekedett az iskolabezárások hatására. Molnár és munkatársai (megjelenés alatt) 21 ezer 2-8. évfolyamos tanuló körében vizsgálta a 2020 tavaszi digitális oktatás hatását az olvasás-szövegértés, matematika és természettudományos tudást tekintve az év azonos időszakában, korábbi években (2018-ban és 2019-ben) tapasztalt átlagos tudásszintekhez viszonyítva. Eredményeik szerint mindhárom vizsgált területen az egy évfolyamon belüli különbségek nagyobbak voltak, mint az évfolyamok közötti mért átlagos fejlődés. 
Az iskolabezárások miatt megváltozott tanulási lehetőségek, körülmények hatása mind az olvasás-szövegértés, mind a matematika, mind a természettudományok területén kimutatható. Míg a 2018-as és 2019-es átlagos teljesítmények között alapvetően nem történt jelentős változás, addig a 2020/21-es tanévben a korábbi két tanévhez képest alacsonyabbnak bizonyult a diákok átlagos teljesítménye a vizsgált területeken.

Néhány, az iskolabezárások idején pedagógusok körében végzett nem reprezentatív online felmérés is készült hazánkban. Gyetvai (2020) a tanárok munkaterhelését vizsgálta, és a kérdőívét kitöltő 1890 pedagógus 82\%-a értett egyet azzal, hogy az online oktatás jelentős többletmunkát igényel. A leterheltség érzésének növekedését Kóródi és munkatársai (2020) 769 pedagógus lekérdezésével végzett vizsgálata és Fekete (2020) tanulmánya is alátámasztja.

Habár a magyar pedagógusok felkészültnek, magabiztosnak érzik magukat az IKTeszközök használatában a tanárokat nemzetközi összehasonlításban vizsgáló TALIS szerint (OECD, 2019), ezen adatok vélhetően csak korlátozottan érvényesek, amennyiben a teljes oktatás online módon zajlik. Kóródi és munkatársai (2020) arról tudósítottak, hogy a nagyobb terhelés mellett az átlagosnál alacsonyabb énhatékonyságról számoltak be a pedagógusok, vagyis a nagyobb erőfeszítésüket nem látták megtérülni a hagyományos munkarendhez viszonyítva. Ezt részben azzal magyarázzák a szerzők, hogy vélhetően nem tudták még hatékonyan használni azokat az online platformokat, amelyeket azonnal, a tanulási folyamattal egy időben használniuk is kellett.

Fekete (2020) kutatásában a Facebookon az Online Otthonoktatás csoportban megosztott bejegyzéseket elemezte. A bejegyzések jelentős része pedagógusoktól származott. A 999 hozzászólás alapján készült elemzésből az online oktatáshoz kapcsolódóan a következő nehézségek rajzolódtak ki: „IT-ismeretek hiánya, az erre irányuló képzés elmaradása, a kellö gyakorlat és az oktatáshoz szükséges eszközök, okostankönyvek, digitális tananyagok hiánya" (Fekete, 2020. 88.). Fekete és Porkoláb (2020) kisebb volumenü ( $n=163)$, középiskolai tanulókra és felsőoktatási hallgatókra kiterjedő felmérésében néhány további kihívás is megjelenik: az informatikai infrastruktúra túlterhelődése, a diákok és a tanárok hiányos platformkezelési ismeretei. A hátrányos helyzetü tanulók további leszakadásának előrevetítése mind Fekete és Porkoláb (2020), mind Fekete (2020) munkájában felmerül. Utóbbiban az internet- és IKT-eszközök hiánya mellett a hiányzó áramszolgáltatás és a hiányos étkezés okozta problémák is megjelennek.

\section{A digitális oktatás lehetséges kihívásai a hátrányos helyzetü tanulók esetében}

Az iskolabezárások hatása a különböző szocioökonómiai hátterű tanulók esetében vélhetően jelentősen eltérő volt, egyrészről az otthoni körülményeik, másrészről az iskolájuk által kínált eltérő szolgáltatások, harmadrészről a többségi tanulókétól eltérő készségfejlettségük miatt. A következőkben a felsorolt területeken megjelenő különbségeket ismertetjük elérhető adatokra támaszkodva.

\section{Otthoni körülmények}

A Központi Statisztikai Hivatal (2020) adatai szerint 2019-ben a háztartások 86\%-a rendelkezett internet-hozzáféréssel, ami 4 százalékkal marad el az Európai Unió átlagától. Egy, a gyermekes családok körében végzett hazai felmérés ugyancsak magas internetelérésről (98\%) és a számítógépek széles körü otthoni birtoklásáról (91\%) tudósít (Ipsos, 2020). Nemzetközi összehasonlításban a legalább egy otthoni számítógépet $(93,6 \%)$ és internetelérést $(96,2 \%)$ tekintve a tizenöt éves magyar diákok helyzete jónak mondható, és a különböző családi hátterü tanulók esetében sem mutatnak az adatok kiugró különbségeket (OECD, 2015). 
Az összességében kedvező adatoknál pontosabb képet rajzol az iskolások és családjaik digitális oktatáshoz szükséges technikai ellátottságáról Hermann (2020) elemzése, amelyhez az Országos Kompetenciamérés 2017-es adatait használta. Eszerint a 6., 8. és 10 . évfolyamon a diákok 12,10 és $7 \%$-a egyáltalán nem elérhető az internet vagy a számítógép hiánya miatt és további 8,6 és $5 \%$ csak korlátozottan érhető el, mivel egy számítógépen legalább három diáknak kellene osztoznia. Összességében ez a diákok 20, 17 és $12 \%$-a a vizsgált évfolyamokon. Az adatok mögött jelentős társadalmi különbségek fedezhetők fel: a 6. és 8. évfolyamon a legfeljebb általános iskolai végzettséggel rendelkező édesanyák gyermekeinek több mint fele nem vagy korlátozottan tud csak bekapcsolódni az online oktatásba. Ez előrevetíti az online oktatás kapcsán tovább erősödő oktatási egyenlőtlenségeket.

Az internet- és eszközellátottság hiányát a tanulók egy kisebb hányada esetében az iskolák által kiadott eszközök és a nyilvános elérési pontok (pl. iskolai számítógép-termek) részben orvosolhatták. Fodor és munkatársai (2020) iskoláskorú gyermeket nevelö szülők körében végzett felmérése szerint a családok egy része új eszközöket szerzett be a digitális oktatás miatt, és ebben nem volt lényeges különbség a szülök iskolázottsági szintje szerint. A legnagyobb magyarországi telefonszolgáltatók ingyenesen biztosítottak internetes adatforgalmat egy meghatározott kvóta erejéig az iskolabezárások idején. Azonban az igénybevétel feltétele a megfelelő eszközök birtoklása volt. Bár az ,internethez való mozgás közbeni (nem otthonról és munkahelyröl) hozzáférés mobil eszközök segítségével" elnevezésű mutató esetében a magyar lakosság alig marad el az Európai Unió átlagától, a legfeljebb általános iskolai végzetséggel rendelkezők körében az elmaradás (12\%) látványos (DESI, 2019). Ez arra utal, hogy az ingyenes internet lehetőségét az iskolabezárás idején a hátrányos helyzetü családok egy jelentős része nem tudta kiaknázni.

További nehézséget jelenthetett a hátrányos helyzetü tanulók számára, hogy a digitális oktatás nagymértékü szülői segítséget igényelt. A nemzetközi összehasonlító vizsgálatok szerint Magyarország lakosságának mindössze 50\%-a rendelkezik alapvető digitális készségekkel, ami elmarad az európai uniós átlagtól (60\%), de a Magyarországhoz sok tekintetben hasonló visegrádi országok közül is csak Lengyelországot (46\%) elözzük meg (DESI, 2019). Az iskoláskorú gyermeket nevelő szülők körében végzett felmérés toknál pontosabb képet rajzol az iskolások és családjaik digitális oktatáshoz szükséges technikai ellátottságáról Hermann (2020) elemzése, amelyhez az Országos Kompetenciamérés 2017-es adatait használta. Eszerint a 6., 8. és 10. évfolyamon a diákok 12, 10 és $7 \%$-a egyáltalán nem elérhetố az internet vagy a számitógép hiánya miatt és további 8, 6 és 5\% csak korlátozottan érhetô el, mivel egy számitógépen legalább három diáknak kellene osztoznia. Összességében ez a diákok 20, 17 és 12\%-a a vizsgált évfolyamokon. Az adatok mögött jelentôs társadalmi különbségek fedezhetôk fel: a 6. és 8. évfolyamon a legfeljebb általános iskolai végzettséggel rendelkezó édesanyák gyermekeinek több mint fele nem vagy korlátozottan tud csak bekapcsolódni az online oktatásba.

Ez elórevetíti az online oktatás kapcsán tovább erốsödó oktatási egyenlótlenségeket.
Az összességében kedvezó ada- 
megerősítette a szülői segítség szükségességét: a kérdezett szülők 78\%-a nyilatkozta, hogy valamilyen mértékü szülői segítségre szorul gyermeke a digitális oktatás kapcsán (Fodor és mtsai, 2020). Gyetvai (2020) kérdőíves adatgyüjtésében a 3074 válaszoló szülö közel 70\%-a értett egyet azzal, hogy többet kell foglalkoznia a távoktatás során a gyermekeik iskolai teendőivel. A válaszadók több mint 60\%-a (elsősorban az általános iskolás diákok szülei) három vagy annál több órát fordítottak naponta gyermekeik iskolai teendőinek támogatására. Ezek alapján minden valószínűség szerint azok az alacsonyan iskolázott szülők, akiknek egyébként is problémát jelent gyermekeik tanulmányainak segítése, további akadályokkal találták szembe magukat az információs-kommunikációs technológiák területén való járatlanságuk miatt.

A megfelelő otthoni tanulási tér hiánya a szegénységben élő családok körében általánosan jellemző. Az alacsonyabb jövedelmü családok körében általában magasabb fokú a stressz, amelyet a gyermekek kognitív és társas-érzelmi fejlődésre negatívan ható egyik legfontosabb tényezőként tartanak számon (pl. Bradly és Corwyn, 2002). Az otthonon kívüli programlehetőségek korlátozottsága a zsúfoltság érzetét, és ezzel a stresszfaktorok jelenlétét vélhetően felerősítette. Ehhez minden bizonnyal gyakran hozzájárult e családok esetében a koronavírus miatti szükülő munkapiaci lehetőségek és jövedelem-kiesés okozta növekvő stressz is. Tudvalevő, hogy a koronavírus a kevésbé képzett munkaerőt kedvezőtlenebbül érintette (pl. Fana és mtsai, 2020; Fodor és mtsai, 2020; Köllö, 2021).

\section{Iskolai szolgáltatások}

A magyar oktatási rendszer extrém mértékben szelektív, az eltérő családi hátterü tanulók egymástól elkülönülve, jellemzően saját szocioökonómiai hátterükhöz hasonló kortársakkal együtt tanulnak. A különböző tanulói összetételű iskolák jelentősen eltérő minőségü oktatási szolgáltatást nyújtanak (Fejes és mtsai, 2020; Radó, 2020; Messing, 2017). Azokban az iskolákban, amelyekben a hátrányos helyzetü tanulók aránya magas, a tanulási problémák kumulálódásának következtében a pedagógiai erőforrások szűkössé válásán, a tanári kontraszelekción, az intézmények korlátozottabb anyagi lehetőségein és a kedvezőtlen motivációs folyamatok kialakulásán keresztül a meglévő családi hátrányok felerősödnek (Kende és Szalai, 2018; Kertesi és Kézdi, 2016; Hajdu és mtsai, 2019).

Az iskolák humánerőforrásában tapasztalható különbségek (Hajdu és mtsai, 2019) vélhetően nemcsak a hagyományos, de a digitális oktatás esetében is hátrányok forrásai. Mindehhez érdemes figyelembe venni, hogy a digitális tanrendre való átállás a túlterheltséget (Kóródi és mtsai, 2020; Gyetvai, 2020) fokozta a pedagógusok körében. A pedagógusok túlterheltségét a hátrányos helyzetü tanulókat magasabb arányban oktató iskolákban vélhetően tovább növelte, hogy a megfelelő IKT-eszközökkel és/vagy internettel nem rendelkező diákjaik részére papíralapon is elö kellett állítaniuk oktatást segítő anyagokat (pl. L. Ritók, 2020). Az említett körülmények az oktatási minőség csökkenését valószínüsítik a hátrányos helyzetü tanulók esetében a digitális oktatás idején.

\section{Eltérő kognitív jellemzők}

A digitális oktatás következtében elvárt otthontanulás a tanulók részéről nagyobb önállóságot, önfegyelmet igényel. Ugyanakkor az ehhez szükséges készségek és affektív jellemzők (pl. szövegértés, digitális írástudás, önszabályozás, tanulási motiváció) jellemzően kevésbé fejlettek vagy kedvezőek az alacsony szocioökonómiai státuszú tanulók esetében (pl. Fejes, 2012; Heckman és mtsai, 2011; OECD, 2018). A digitális szövegértést is mérő PISA-vizsgálat eredményei szerint a magyar tanulók teljesítményük alapján az utolsók Európában. A gyenge átlagteljesítmény mellett az is lényeges, hogy e területen a teljesítmény és a szocioökonómiai státusz kapcsolata különösen erős Magyarország 
esetében, a vizsgálatban részt vevő 31 ország (és gazdaság) között a második legerősebb. És különösen nagy volt a különbség a digitális írástudásban azok között, akiknek volt és akiknek nem volt lehetősége otthon számítógépet használni (OECD, 2015). Vagyis Magyarországon a hátrányos helyzetü tanulók többsége esetében a gyenge digitális szövegértés alapvető akadálya lehet a digitális oktatásnak.

Az alacsonyabb szocioökonómiai státuszú tanulók körében a nyári szünetet követő teljesítmény-visszaesés (summer learning loss, summer setback, summer slide) jól ismert jelenség. A digitális oktatásra való átállás e jelenséghez hasonlítható, amit vélhetően felerősít, hogy valóban össze is folyt a nyári szünettel. Bár nemcsak az olvasás terén azonosították e jelenséget, az olvasási teljesítményt tekintve jelentősebb lemaradást tapasztaltak a hátrányos helyzetű tanulóknál, mivel a kedvezőbb családi hátterü tanulók teljesítménye jellemzően pozitív irányba változik a nyári szünidő alatt (Cooper és mtsai, 1996). A különbségek növekedésének egyik oka vélhetően a szabadidős olvasási szokások eltérésében keresendő. A szabadidős olvasás eltérő szokásaiból eredő teljesítménycsökkenés akár már a tanév folyamán megjelenhetett a hátrányos helyzetủ tanulók körében.

\section{Célok}

2020 áprilisában online kutatás végeztünk hátrányos helyzetü és roma gyermekeket is oktató pedagógusok körében a digitális oktatásra történő átállással kapcsolatos első tapasztalataik kapcsán. Tanulmányunkban a tanárok tapasztalatainak tükrében vizsgáltuk a digitális átállás nehézségeit. Munkánk kiemelt célja volt, hogy a lehető leghamarabb információt szerezzünk arról, hogy a hátrányos helyzetü és roma tanulók milyen nehézségekkel küzdenek a digitális oktatásra történő átállás során, és az eredményekre alapozva az oktatásirányítás és a szélesebb közvélemény figyelmét felhívjuk ezekre a mihamarabbi beavatkozás érdekében. ${ }^{1}$

A következő területeken feltételeztünk problémákat a digitális oktatásra való átállás kapcsán: rendelkezésre álló IKT-eszközök és internetelérés; tanulók, szüleik és pedagógusok digitális kompetenciái; tanulók szövegértése; tanuló és iskola közötti kapcsolattartás (kommunikáció, tanulássegítés, feladatkiadás). Emellett általánosságban is igyekeztünk megismerni a digitális oktatás mindennapjainak első tapasztalatait és a pedagógusok véleményét a kialakult helyzettel kapcsolatban. A tanulmány fő szervező szempontja az, hogy összehasonlítsa a roma, illetve halmozottan hátrányos helyzetü gyermekeket magas, illetve alacsony arányban oktató pedagógusok tapasztalatait, és következtetéseket vonjon le a járvány oktatási egyenlőtlenségekre vonatkozó hatásáról.

\section{Az empirikus vizsgálat részletei}

\section{A kutatás módszerei, az elemzésben felhasznált adatok forrása}

Kutatásunk a lehető leggyorsabban kívánt térképet rajzolni arról, hogy hogyan hat az iskolák digitális átállása a halmozottan hátrányos helyzetü (továbbiakban $\mathrm{HHH})^{2}$ és roma gyermekekre és az őket tanító pedagógusokra. Ennek érdekében online kérdőívet állítottunk össze, amelyet különböző online fórumokon és pedagóguscsoportokban címeztünk olyan pedagógusoknak, akik HHH/roma gyermekeket oktatnak. ${ }^{3}$ A kutatásban való részvétel önkéntes volt, a kérdöív kitöltése anonim módon történt. A kérdöív három hétig volt elérhetö, és ez idő alatt 425 pedagógus töltötte ki; ez képezi elemzésünk mintáját. A minta nem reprezentatív, erre az online platform és az idő rövidsége miatt nem is volt lehetőség, de feltételezhetjük, hogy a kérdőívet nagyobb arányban töltötték ki olyan pedagógusok, 
akik motiváltabbak a digitális oktatás megvalósításában, így valószínű, hogy a valóságosnál kedvezőbb helyzetet mutatnak az adatok. Az online survey adatait roma és roma közösségeket segítő civilszervezetek vezetőivel készült felmérésből, ${ }^{4}$ valamint három iskolaigazgatóval készített interjúkból származó idézetekkel egészítjük ki. Ezek kiválasztása, megszervezése azonban nem követett elöre meghatározott módszertani eljárásokat.

Az online kérdőívet kitöltő tanárokat arra kértük, hogy becsüljék meg a roma és a HHH tanulók arányát az iskolájukban, illetve azokban az osztályokban, ahol tanítanak. Elemzésünk során elsősorban az osztályszintü becslést használtuk, hiszen a válaszoló pedagógusoknak pontosabb rálátása van az általuk tanított osztályokra, mint az iskola egészére. A következő kategóriák közül választhattak: 0-20\%, 20-40\%, 40-60\%, 60-80\%, 80-100\%. Mivel arra számítottunk, hogy a kérdöívet elsősorban olyan pedagógusok töltik ki, akik nagy arányban oktatnak HHH és/vagy roma tanulókat, a különbözö tanulói összetételü iskolák és osztályok összehasonlításának lehetőségével a kérdőív összeállítása során nem számoltunk. Ugyanakkor a kitöltőknek az említett szempont szerinti heterogén mintája fontos viszonyítási pontokat kínál a $\mathrm{HHH}$ és roma tanulók helyzetének bemutatásához.

A hazai szakirodalomhoz igazodva (pl. Havas, 2008; Havas és Liskó, 2005; Papp Z., 2011; Szücs és Kelemen, 2013; Zolnay, 2007) a kutatás során az iskola (illetve osztály) összetételét tekintve négy csoportot különböztettünk meg: ahol a $\mathrm{HHH}$, illetve a roma gyerekek becsült aránya az országos átlagnál alacsonyabb (0-20\%), vegyes összetételü iskolák (20-40\%), szegregációs pályán lévő (40-60\%) és szociálisan és/vagy etnikailag szegregált iskolák (60-100\%). Mivel a két kategória (HHH, roma) gyakorlatilag statisztikai hibahatáron belüli különbségeket mutatott, nem részletezzük az eredményeket külön a két csoportra vetítve. Ez azonban nem jelenti azt, hogy összemosnánk a roma és a HHH gyermekek fogalmát; tisztában vagyunk vele, hogy ezek alapvetően eltérő csoportok, eltérő közpolitikai megközelítést igényelnek, mégis fontos eredménye kutatásunknak, hogy a pedagógusok percepciójában a $\mathrm{HHH}$ és a roma kategória erősen összemosódik (Messing, 2014; Messing és Bereményi, 2017).

\section{Minta: a kérdöívre válaszolók legfontosabb jellemzöi}

A kitöltők meghatározó többsége nő volt, átlagéletkoruk 58 év. Átlagosan 23 éve vannak a pedagógusi pályán, ami nagyon hasonló ahhoz, mint ami a magyar pedagógustársadalom egészét jellemzi. Tehát általánosságban elmondható, hogy nagy tapasztalattal rendelkezö, pályájuk vége felé közelítő és jellemzően női pedagógusok osztották meg tapasztalataikat.

Míg a válaszoló pedagógusok kétharmada tanít általános iskolában, a HHH/roma többségü osztályokban tanító kitöltők közel 80\%-ban általános iskolai tanárok nagyjából, hasonló arányban az alsó- és felső tagozatban. Tehát az állítások nagyon nagy része az általános iskolai oktatásra vonatkozik, azon belül is a válaszadó pedagógusok nagy többsége (83\%-a) állami iskolában dolgozik, tehát tapasztalataik jól tükrözik, hogy mit észlelnek a pedagógusok az elmúlt hetek digitális átállása kapcsán a Tankerületi Központok segítségnyújtásából.

A halmozottan hátrányos helyzetü és roma népesség megoszlását közli a válaszoló tanárok területi megoszlása szerint az 1. ábra (minél nagyobb a kör, annál több tanár válaszolt a kérdőívre az adott területi egységben, a körök árnyalata pedig a $\mathrm{HHH} / \mathrm{roma}$ gyerekek becsült arányát tükrözi az adott iskolában). A legsötétebb körök gyakorlatilag szegregált iskolákat mutatnak, ahol a $\mathrm{HHH} /$ roma gyerekek aránya $60 \%$ fölötti): legfóképp Kelet-Magyarországon és azon belül is Északkelet-Magyarországon és az ország dél-nyugati megyéiben (Baranya, Tolna) oktatnak. A tanárok 37\%-a községi, 31\%-a kisvárosi iskolában és harmada megyeszékhely vagy Budapest iskoláiban tanít. A szegregált 
iskolák sokkal nagyobb aránya található községekben (a községi iskoláknak több mint fele nevezhető szociálisan és/vagy etnikailag szegregáltnak).

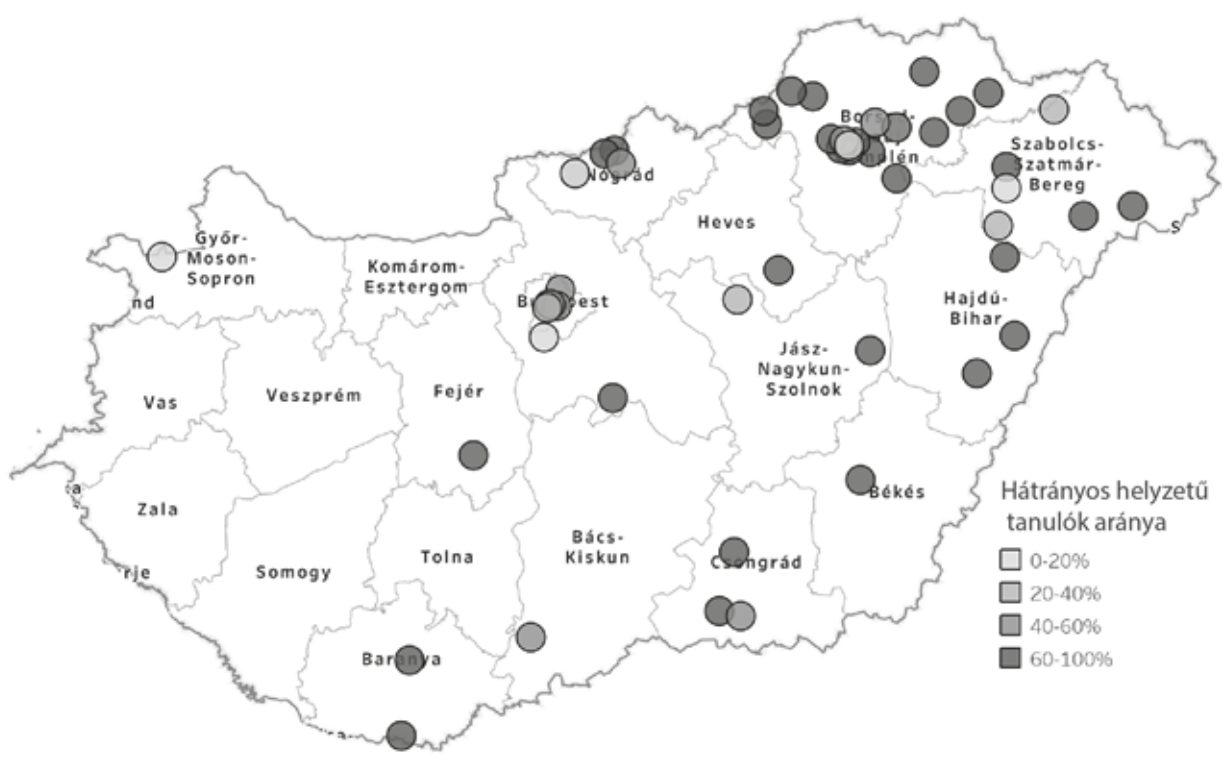

1. ábra. A survey mintájának földrajzi megoszlása az iskolák HHH-aránya szerint

\section{Eredmények}

\section{Digitális oktatáshoz való hozzáférés: technikai és személyi akadályok}

A digitális oktatás alapvető feltétele, hogy legyen a tanároknak és a diákoknak internet-hozzáférésük és olyan eszközük, amelyen az oktatás megvalósulhat. A kérdőívet kitöltő tanárok döntő többsége korlátlan internet-hozzáféréssel rendelkezett, és ebben nem volt nagy eltérés sem a település típusa, sem aszerint, hogy az adott iskolában mekkora a $\mathrm{HHH}$ vagy roma tanulók aránya. Érdemes visszaemlékezni arra, hogy a tavaszi leállásokra válaszul a nagy internetszolgáltatók 10/15/100 GB-os mobil adatforgalmi egyenleg díjmentes biztosítását jelentettek be. ${ }^{5}$ A kérdöívet a tanárok ebben az időszakban töltötték ki, így gyaníthatóan e kedvezmény április végi beszükülése, illetve megszünése radikálisan változtatott a hátrányos helyzetü diákok internetelérésén. Telefonja és laptopja/számítógépe szinte minden válaszadónak volt, sőt pozitív fejleménynek tartjuk, hogy különösen a magas $\mathrm{HHH} /$ roma-arányú iskolákban tanító válaszadóink kétharmadának az iskola biztosítja a laptopját vagy a számítógépét. Ebben a csoportban a válaszolók több mint fele válaszolta azt, hogy részt vett korábban digitális oktatással kapcsolatos képzésen, és azon belül is több mint a fele azt mondta, hogy ezt ebben az időszakban hasznosítani is tudja.

A digitális oktatásba való bekapcsolódás már korántsem ilyen kedvező a tanulók oldaláról: egyértelmünek tünik, hogy minél nagyobb a $\mathrm{HHH} /$ roma diákok aránya, annál alacsonyabb a digitális oktatásban részt vevők aránya is (2. ábra, Khí-négyzet $=40,2 ; p=0,00)$. Míg a jó szociális helyzetü tanulókkal jellemezhető iskolákban a diákok átlagosan $84 \%$-a vett részt az oktatásban az iskolabezárás idején, ez az arány már csak kétharmad volt azokban az osztályokban, ahol magas a HHH/roma diákok aránya (60\% feletti). 


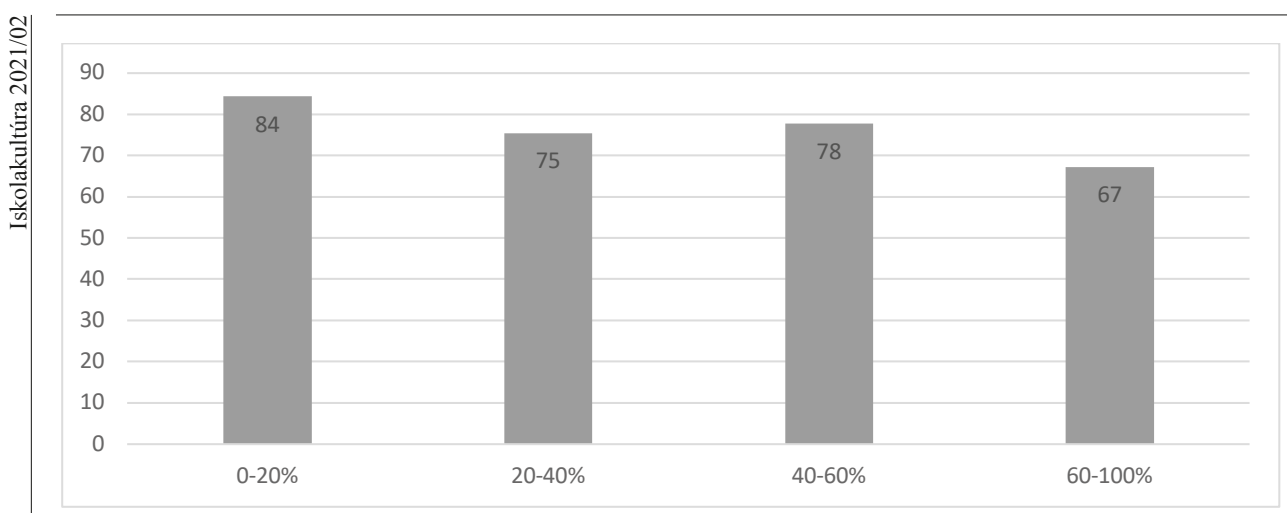

2. ábra. A digitális oktatásba bekapcsolódó, illetve abból kimaradó diákok\%-os aránya az iskolák HHH-aránya szerint

Érdemes ráközelíteni az oktatásból kimaradó diákokra. A kutatásban részt vevő tanárok becslése szerint átlagosan diákjaik 16\%-a esett ki az oktatásból a digitális átállás első hónapjában. Fontos hangsúlyozni, hogy munkánk a digitális átállás legelső időszakára, az első néhány hétről ad képet; nagy valószínüséggel a félév során a fentieknél nagyobb arányban veszítettek tanulókat az iskolák (ld. Hermann, 2020 elemzésének következtetéseit). Sajnos arra vonatkozóan nincsenek még elérhető statisztikai adatok, hogy a 2019/20-as tanévben hogyan alakult az évismétlések és az oktatásból korán kieső diákok száma, pedig talán ez a két legfontosabb mutató, amelyre támaszkodva objektíven megítélhető lehetne a kényszerü digitális átállás sikeressége.

A család szociális helyzete egyértelmü szakadékot képez abban a tekintetben, hogy a tanuló mekkora eséllyel esett ki az oktatásból a digitális oktatásra való átállás során: míg az alacsony HHH/roma-arányú osztályokat oktató tanárok mindössze 7\%-a mondta, hogy a diákok felénél több diákja elveszett az átállás során, ez az arány $28 \%$ a magas HHH/roma-arányú osztályokban (3. ábra, Khí-négyzet = 28,3; p =0,00).

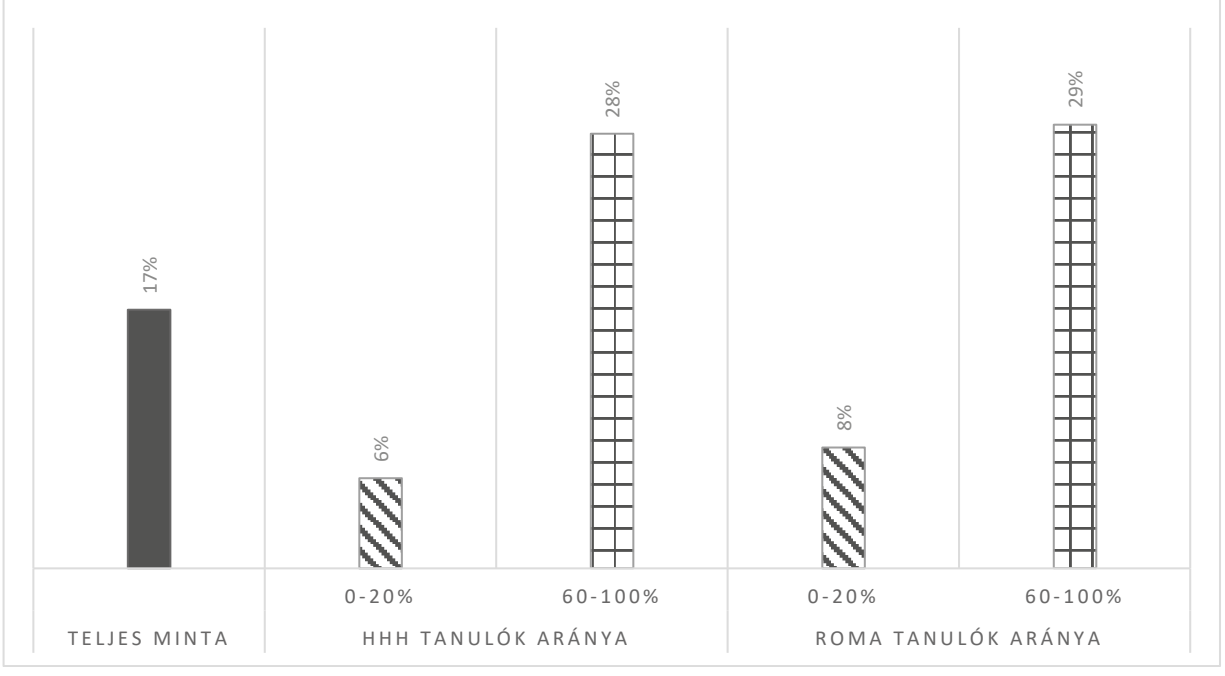

3. ábra. A tanulók több mint felét elvesztö osztályok szociális és etnikai összetétel szerint 
A korábbi állításokkal összhangban elsősorban azokon a területeken koncentrálódnak a magas kiesési arányt jelző pedagógusok iskolái, ahol egyébként is magas a hátrányos helyzetü és roma gyermekek aránya (4. ábra). Figyelemreméltó a magas kiesési arányú iskolák koncentrálódása Északkelet-Magyarországon, azon belüli is Borsod-AbaújZemplén megyében (4. ábra), miközben például Baranya megyében, ahol szintén jelentős számú HHH/roma gyerekeket oktató iskola került a mintánkban (1. ábra), alig-alig jelentettek magas kiesési arányokat a pedagógusok. Ennek magyarázatához további elemzésekre lenne szükség.

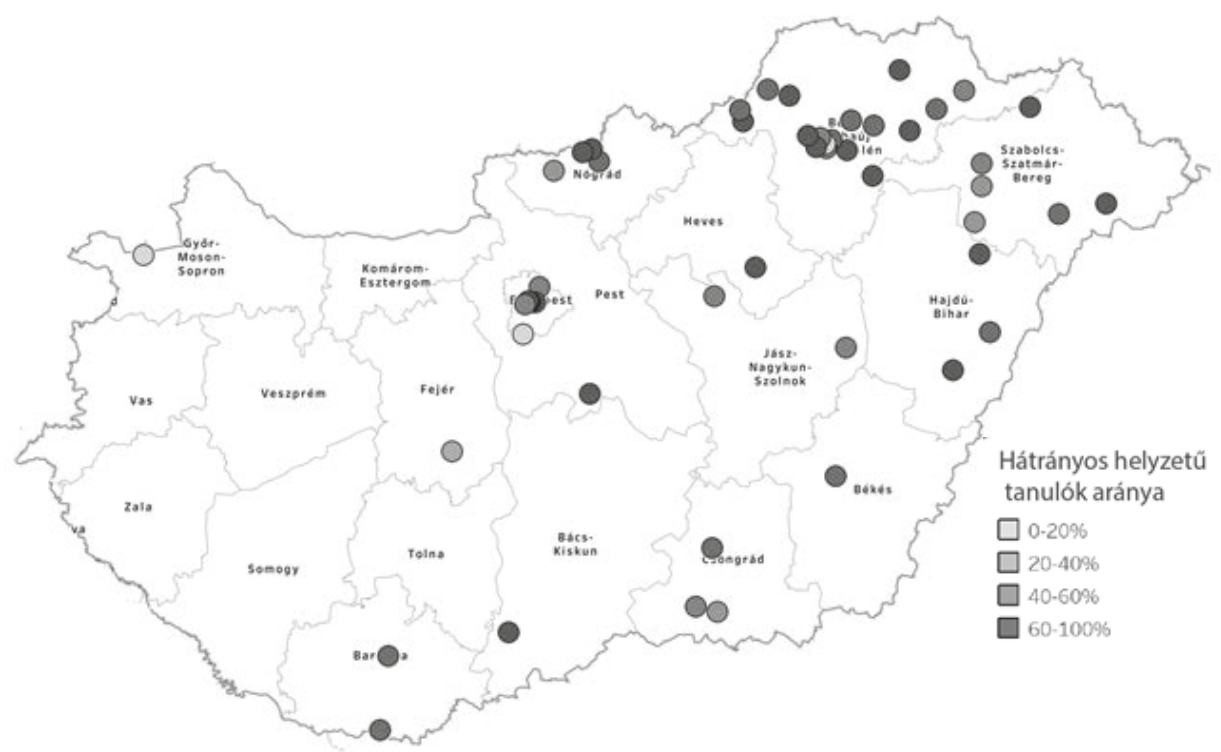

4. ábra. Az oktatásból a digitális átállás elsö hónapjában kiesett tanulók aránya az iskolák HHH-aránya szerint

\section{A digitális oktatásba bekapcsolódó tanulók nehézségei}

Rákérdeztünk arra is, hogy a pedagógusok mit tételeznek a diákok kimaradásának okairól. Első helyen a megfelelő infrastruktúra hiányát jelölték meg, függetlenül attól, hogy milyen összetételü iskolában tanított a válaszadó. Bár a hátrányos helyzetü gyerekeket nagy arányban oktató iskolákban a pedagógusok közel fele ezt jelölte meg elsődleges okként, a jó helyzetü gyerekek között is ez a leggyakoribb ok (37\%) volt. A megfelelö infrastruktúra hiánya több mindent jelenthet: elsősorban a megfelelő eszköz (számítógép, laptop) hiánya vagy szükössége, illetve a megfelelö internetkapcsolat hiánya. A megfelelö eszköz hiánya akkor is előfordulhat, ha van ugyan a háztartásban számítógép, azt azonban sokan kellene, hogy használják (Hermann, 2020). Emellett az is gyakori lehet, hogy csak mobileszközön keresztül van a tanulóknak internetelérése, hiszen mobiltelefonon üzenni, levelet írni ugyan lehet, de azon keresztül online oktatásban részt venni már problémásnak tünik.

„Van, ahol több gyerek van, és csak egy tudja használni a gépet, a másik kettő nem, mert a tananyagokat egymás után teszik fel, és egyszerre nem tudja mind csinálni, mert várni kell a másikra, addig ő kimarad, és vagy tudja később pótolni, vagy lemarad a többitöl” (közösségi vezetővel készült interjú részlete) 
A megfelelő infrastruktúra hiánya azonban nem kizárólagos oka annak, hogy a diákok nem elhanyagolható része kimaradt az oktatásból (5. ábra). Minden ötödik tanár egzisztenciális okokat jelzett (pl. a gyerekeknek is be kell kapcsolódniuk a megélhetés biztosításába, háztartási munkákba, kisebb gyerekek felügyeletébe). Nem világos, hogy hova - azaz egzisztenciális vagy infrastrukturális okok közé - sorolták a válaszadó tanárok azt, amikor nem megfelelő a tanuláshoz az otthoni környezet. A jobb társadalmi helyzetü tanulókat oktató iskolákban a tanárok közel harmada azt jelezte, hogy az oktatásból kimaradó diákok egyszerüen nem reagálnak a megkeresésükre, tehát a tanár nem tudja, hogy mi az oka annak, hogy nem tud vele kommunikálni. Ök úgy vesztek el az iskola látóköréből, hogy a tanár nem ismeri az okot. A HHH és roma diákokat oktató iskolában az ilyenfajta „eltünést” valamivel gyakrabban tulajdonítják a pedagógusok ,érdektelenségnek” vagy „lustaságnak” („már korábban sem érdekelte az iskola”; ,,azt gondolják, hogy szünet van").

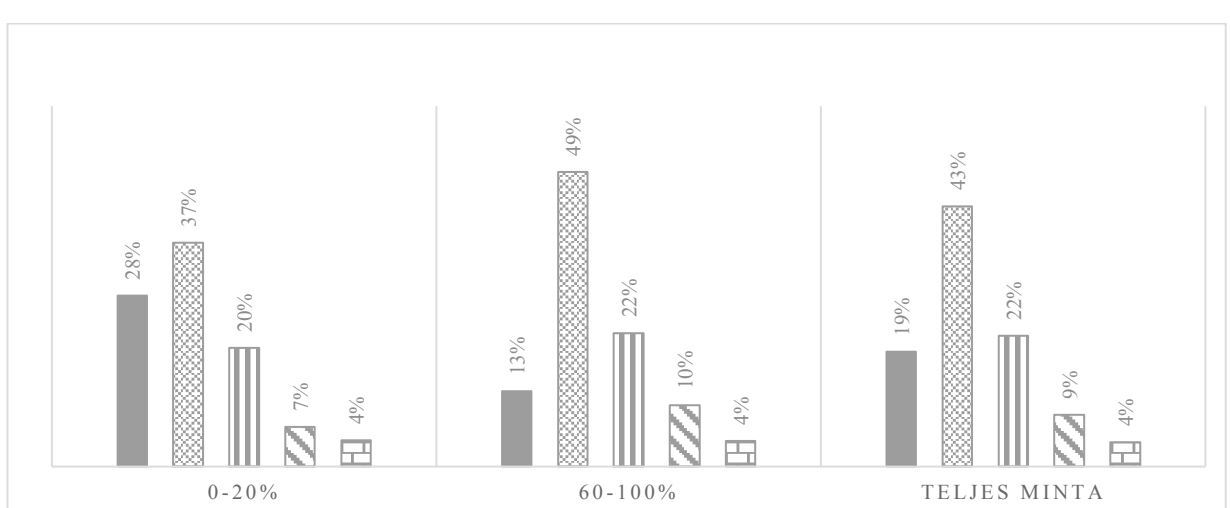

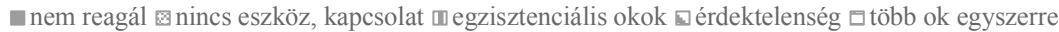

5. ábra. A digitális oktatásból való kimaradás legfontosabb okai a tanárok észlelése alapján a HHH tanulók aránya szerint és a teljes mintán

A magyar háztartások többségére, de a hátrányos helyzetüek szinte mindegyikére jellemző, hogy nincs minden gyermeknek saját szobája, tere; márpedig nagyon nehéz az iskolát követni akkor, amikor egy térben zajlanak a hétköznap eseményei (pl. fözés, étkezés, kisebb gyermekek játéka) és az iskolás testvérek tanórái. A HHH/roma többségü iskolákban tanító válaszadóink a legnagyobb nehézséget a tanulásra alkalmas tér hiányának tulajdonították.

Az oktatásba bekapcsolódott diákok esetében a válaszadó tanárok zöme a tanulói összetételtöl függetlenül jelezte, hogy a távoktatásban súlyos akadályt jelent, hogy a diákok nehezen vagy egyáltalán nem tudják önállóan értelmezni a feladatokat (6. ábra). A szakirodalmi áttekintésben felvázoltuk a digitális átállás szélesebb kontextusát, ezen belül a magyar diákok önálló tanulási készségének és értő olvasásának alacsony szintjét. Ez egy nagyon egyszerü összefüggés: ha a tanulók otthon, tanári segítség hiányában kell tanulnia, úgy az önálló tanulás készsége és az értő olvasás kulcskészségek, amelyek hiánya nagyon komoly akadály, és csak szülöi felügyelettel, segítséggel orvosolható. Ahogy a szakirodalmi áttekintésben rámutattunk, minden családot, de különösen az anyákat rendkívül megterheli e helyzet. Azonban a hátrányos helyzetű tanulók esetében ez további hátrányt jelent, hiszen az ő szüleik általában alacsonyabb iskolai végzettséggel rendelkeznek, nem ritkán maguk is olvasási nehézségekkel küzdenek, tehát még ha 
idejük lenne is rá, akkor sem tudnának érdemben segíteni gyermekeiknek a tanulásban. Az alábbi két interjúrészlet jól tükrözi, hogyan rakódnak egymásra a hátrányok egy ilyen feszített helyzetben.

„[A szülők] 90\%-ának, főképp az anyukáknak ez nagyon megterhelö, hiszen a mindennapi teendők mellett segíteni kell a gyermekek tanulását. [...] [Az egyik iskolában] a gyermekek 60\%-a még papíralapon sem tud tanulni, hiszen a szülők többsége iskolázatlan.” (közösségi szervezet vezetője)

„[D]e ha van is eszközük, nincs meg a család digitális tudása ahhoz, hogy változatosan használni tudja (például egy Zoomba vagy Google Classroomba belépés megugorhatatlan kihívás a legtöbb szülönek, de a Kréta rendszer használata vagy egy email fiók kezelése is).” (közösségi szervezet munkatársa)

Természetesen az önállóságot a tanulók életkora is befolyásolja. Ugyanakkor tény, hogy a magyar oktatást hagyományosan a hierarchikus viszonyokon és a lexikális tudásátadás dominanciáján alapuló módszerek jellemzik, és kevés az olyan innovatív megközelítés, amely megkívánja, illetve fejleszti a gyerekek kreativitását, önállóságát és kritikai gondolkodását. Ez a pedagógiai megközelítés most visszaüt, hisz maguk a tanárok szerint is komoly akadály, hogy a gyerekek nem tudnak önállóan feladatokat és helyzeteket megoldani.

Tanláshoz megfelelő tér hiánya otthon

Önállóság hiánya

Nem tudják használni az eszközöket

Internet kapcsolat hiánya

Digitális eszköz hiánya

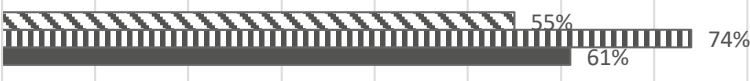

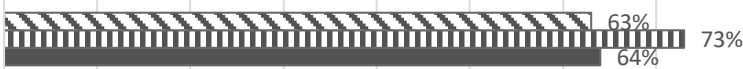

ілымा

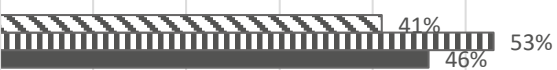

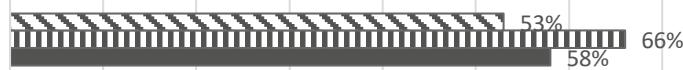

$20 \%$

$30 \%$

$40 \%$

$50 \%$

$60 \%$

@ HHH gyerekek aránya 20\%>

ID HHH gyerekek aránya $60 \%<$

- teljes

6. ábra. Az otthoni tanulás akadályai a tanárok észlelése alapján

\section{A kapcsolattartás és oktatás módja}

Lényeges kérdés, hogy a válaszadó tanárok mit értettek az oktatásba történő bekapcsolódáson. Ennek nagyon sok szintje és minősége lehet, a napi több kontakt online órától kezdve egészen addig, hogy a gyerek hetente kap egy 'házi' feladat listát, és azt hasonló gyakorisággal visszaküldi. Bekapcsolódás-e az, ha papíron kapja meg hetente egyszer a heti feladatokat és olvasmányokat, de sem oktatásra és magyarázatra, sem személyes számonkérésre nincs mód? Ezt a témát párhuzamosan több módon is megpróbáltuk feltérképezni a kérdőíven és a kiegészítő interjúkban is. A kérdőíven egyrészt megkérdeztük a tanárokat, hogy milyen technikai eszközzel tart kapcsolatot a diákokkal, illetve azt, hogy milyen módszereket alkalmaz a válaszadó tanár a digitális oktatás során. 
A válaszokból kirajzolódik, hogy a legtöbbet használt platform a Messenger. Az sajnos nem látszik, hogy ezt pontosan milyen eszközön (pl. telefonon, tableten, számítógépen), és hogy mire használják (pl. chatelésre, csoportos egyeztetésekre, személyes megkeresésre, vagy akár csoportos videóórákra).

A pedagógusok meglepően keveset használják kommunikációra az e-mailt, de sokat telefonálnak, ami különösen meglepö, figyelembe véve, hogy - ahogy korábban kiderült - a tanárok saját tulajdonú telefonnal és valószínüleg saját előfizetésük terhére bonyolították e hívásokat. Egyértelmü, hogy a diákok társadalmi helyzete erősen befolyásolja, hogy milyen platformon kommunikálnak: a Messenger minden csoportban a legfontosabb kommunikációs csatorna, de míg a hátrányos helyzetü és a roma gyerekek számára a telefon a második kommunikációs csatorna és az e-mail nemigen müködik (csak kevesebb mint negyedük használja azt), a jól szituált családok gyermekeit oktató iskolákban az e-mail a chaten kívül a meghatározó csatorna.
Egyértelmú, hogy a diákok társadalmi helyzete erôsen befolyásolja, hogy milyen platformon kommunikálnak: a Messenger minden csoportban a legfontosabb kommunikációs csatorna, de míg a hátrányos helyzetú és a roma gyerekek számára a telefon a második kommunikációs csatorna és az e-mail nemigen müködik (csak kevesebb mint negyedük használja azt), a jól szituált családok gyermekeit oktató iskolákban az e-mail a chaten kivül a meghatározó csatorna.

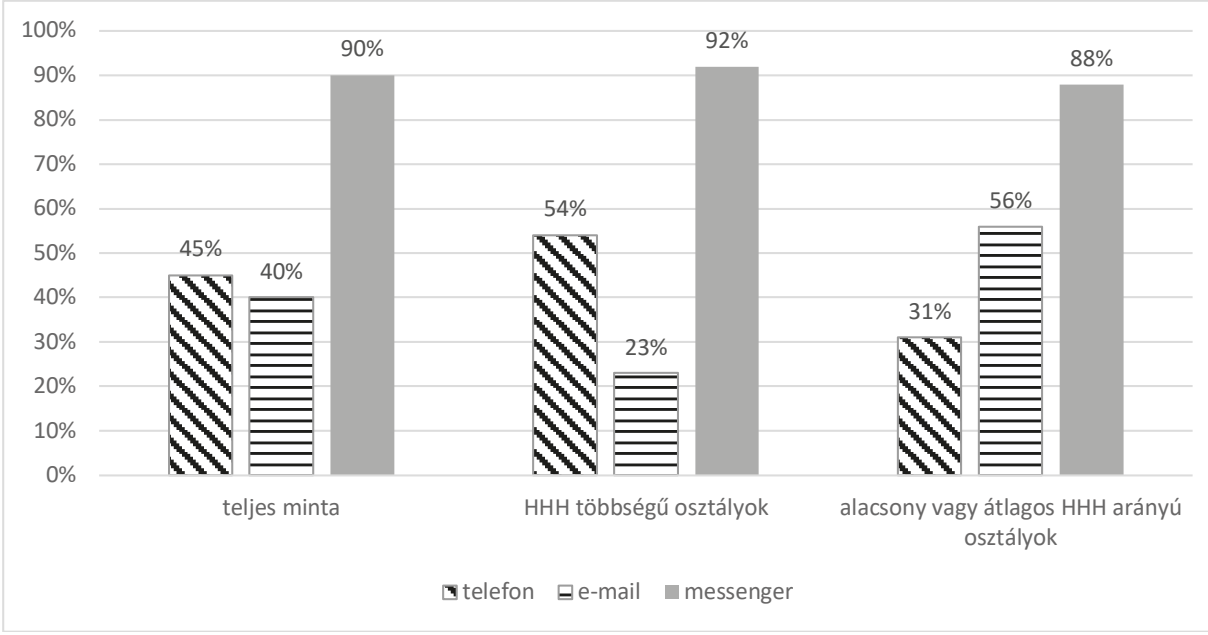

7. ábra. A tanulókkal való kapcsolattartás módjai

Egy szinte kizárólag hátrányos helyzetű roma gyermekeket oktató iskola igazgatójával készült interjú szemléletesen világít rá arra, hogy a digitális kompetencia hiánya a kapcsolattartás egyik alapvető akadálya. Egy főként HHH tanulókat oktató további iskola igazgatójával készült interjú is a Messenger használatának dominanciáját támasztja alá. 
„Most éppen egy közös online platformra próbáljuk áttenni az összes oktatást, mindenkinek e-mailt nyitni és ennek segítségével a Google classroomokat üzemeltetni. Ez nem egyszerü, sok gyereknek a tanítók papíron juttatják el az e-mail címüket, és kérik öket, hogy lépjenek be, több-kevesebb sikerrel."

„Jelenleg a gyerekeket Messengeren keresztül érik el, feladatlapokat is így küldenek nekik, telefonon töltik ki és küldik vissza", ugyanakkor azt is hozzáteszi, hogy „,jelenleg minden mobilszolgáltató biztosít ingyenes havi internet-csomagokat, ezeket használják a diákok, de a következő probléma, ami most kezd a hó vége fele kirajzolódni, az az, hogy a családok elhasználták már a csomagjukat, és a gyerek egyszer csak elérhetetlenné válik."

Az interjú időpontjában a szolgáltatók egy hónapra hirdették meg a bővített adatforgalom ingyenességét, ezt azonban később meghosszabbították, bár már nem egyetemlegesen.

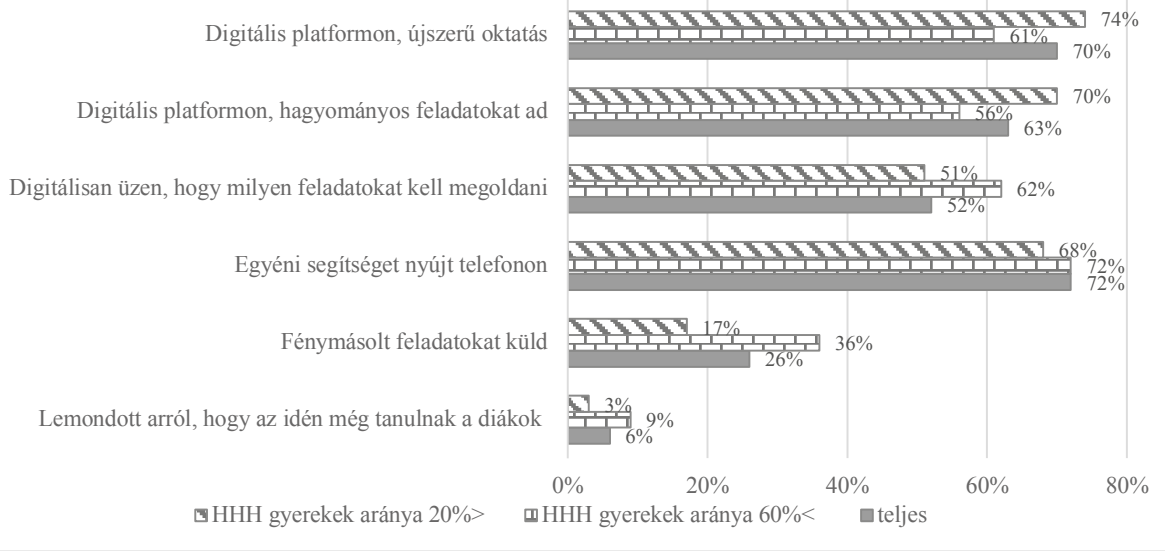

8. ábra. Távoktatásban alkalmazott módszerek

Arra a kérdésre, milyen tartalommal tölti meg a tanár jelen helyzetben az oktatást, egy másik kérdéssor ad képet. A válaszok egyszerre biztatóak és aggasztóak: a tanárok, saját bevallásuk szerint, sokféleképpen használják a digitális oktatást, párhuzamosan alkalmaznak különböző módszereket. 70\%-uk újszerü módokon (is) használja a digitális oktatást. Ugyanennyien jelezték, hogy hagyományos módszerekkel és tananyagokkal (is) töltik meg a 'digitális iskolát'. Ezt a két választ lehet valamilyen módon digitális oktatásnak tekinteni: összesen a válaszadó tanárok $85 \%$-a jelezte, hogy valamely digitális oktatási módszert alkalmaz. A fennmaradó opciók gyakorlatilag offline módszerek: a tanárok fele üzen, hogy milyen tananyagot kell elsajátítani otthon, önállóan a tankönyvböl, illetve milyen feladatokat kell megoldani a munkafüzetből, és sokan postán vagy falugondnok segítségével küldik meg a feladatokat diákjaiknak. Emellett a telefonos segítségnyújtás a tanulók és szüleik számára igen elterjedt kiegészítő eszköze a kényszerü digitális oktatásnak.

Habár, ahogy korábban jeleztük, a válaszadók nem reprezentálják a teljes magyar pedagógustársadalmat - valószínüleg az átlagosnál elszántabbak, jobban informáltak és a digitális oktatás kapcsán alakuló szakmai csoportokba jobban beágyazottak -, a fenti kép ezzel együtt is elég biztató. A tanárok váratlanul és hatalmas kihívással néztek szembe, és úgy tünik, hogy - legalábbis a kérdőívünkre válaszoló tanárok - meglehetősen 
innovatívan és különböző eszközöket, platformokat, módszereket kombinálva próbálják meg megoldani a jelen helyzetben az oktatást.

Aggasztó ugyanakkor a 8. ábra alapján kirajzolódó szétszakadás: a zömmel $\mathrm{HHH} /$ roma gyermeket oktató tanárok kicsit több mint fele használ valamilyen digitális oktatási tartalmat, de ebben a körben nagyon nagy jelentősége van az offline módszereknek is: közel harmaduk fénymásolt tananyagokat juttat el a diákokhoz, vagy megüzeni más módon, hogy milyen tananyagot kell elsajátítani. Ráadásul az utóbbi gyakorlat aránya megközelíti a 70\%-ot a falvakban. A papíralapú oktatás jelentősége a romákat segítő civil szervezetek és közösségi vezetőkkel készült interjúkból is kiviláglik.

„Igyekeztek [a tanárok] gyorsan váltani, és megszervezni magukat. Papírlapon juttatják el a szülőkön keresztül a házi feladatokat. A tanodába is kiküldik minden héten, hogy tudjuk követni, hogy mi a feladat."

A leghátrányosabb helyzetű gyerekeket oktató iskolák igazgatóival készült interjúkból az is kiderült, hogy számos iskola az ebédosztással összekötve tartotta a kapcsolatot diákjaival, offline. Ilyenkor kapták meg a gyerekek a feladatlapokat, amit hetente kellett kitöltve visszaküldeniük. Máshol a falugondnok vitte házhoz a feladatlapokat. Nyilvánvaló, hogy ebben a körben ez nem igazán minősül oktatásnak, hiszen a tananyag átadása nem történik meg, és a középosztálybeli családokkal ellentétben ebben a

A leghátrányosabb helyzetú gyerekeket oktató iskolák igazgatóival készült interjúkból az is kiderült, hogy számos iskola az ebédosztással összekötve tartotta a kapcsolatot diákjaival, offline. Ilyenkor kapták meg a gyerekek a feladatlapokat, amit hetente kellett kitöltve visszaküldeniük. Máshol a falugondnok vitte házhoz a feladatlapokat. Nyilvánvaló, hogy ebben a körben ez nem igazán minốsül oktatásnak, hiszen a tananyag átadása nem történik meg, és a középosztálybeli családokkal ellentétben ebben a körben nem valószínú, hogy a szülók otthon el tudnák magyarázni a tananyagot, vagy felügyelni tudnák a tanulás folyamatát, hiszen jó eséllyel ók maguk is alacsonyan iskolázottak, súlyos egzisztenciális nehézségekkel küzdenek, és vélhetốen általában is több gyermek közt oszlik meg a szülói figyelem. körben nem valószínű, hogy a szülök otthon el tudnák magyarázni a tananyagot, vagy felügyelni tudnák a tanulás folyamatát, hiszen jó eséllyel ők maguk is alacsonyan iskolázottak, súlyos egzisztenciális nehézségekkel küzdenek, és vélhetően általában is több gyermek közt oszlik meg a szülői figyelem.

\section{Segitség a családoknak, segitség a pedagógusoknak}

A nemzetközi szakirodalomban a koronavírus okozta helyzetet többen úgy emlegetik, hogy ,a legnagyobb kihívás, amellyel az oktatási rendszerek valaha szembesültek” (pl. Daniel, 2020). A váratlan és egyedi helyzetben joggal várható, hogy a fenntartó, illetve az oktatásirányító szervezetek szakmai és infrastrukturális támogatást biztosítanak a tanároknak és családoknak. Azonban a kérdezettek válaszai meglehetősen lesújtó képet nyújtanak: 56\%-uk szerint a diákok és a szülők nem kapták meg az átálláshoz szükséges 
segítséget, és a tanárok közül is csak minden ötödik gondolta úgy, hogy kaptak egyáltalán segítséget. Az arány még rosszabb azokban az iskolákban, amelyekben nagyon magas a hátrányos helyzetủ és a roma diákok aránya. Ezekben az intézményekben a tanárok $60 \%$-a gondolta úgy, hogy a családok nem kaptak megfelelő segítséget, miközben nyilvánvaló, hogy pont e családok szorultak volna rá leginkább a támogatásra, hiszen valószínü, hogy sem a technikai tudás, sem az eszköz, de a szülői háttér is sokkal kevésbé áll rendelkezésre a helyzethez való alkalmazkodáshoz. Amennyiben a tanárok percepciója jól tükrözi a valóságot, úgy egyértelmü, hogy a kialakult helyzet és annak kezelése tovább mélyíti a magyar oktatás nemzetközi viszonylatban is szélsőséges egyenlőtlenségeit.

A tanároknak nyújtott támogatás talán még fontosabb lenne egy ilyen helyzetben, hiszen az amúgy is - óvatosan fogalmazva - zömében nem a digitális korszak gyermekeiként szocializálódott pedagógusok (emlékezzünk, az átlagéletkor 58 év) jelentős részének szüksége lehetett technikai segítségre, hogy az oktatást egyik napról a másikra digitálisan nyújtsa diákjai számára. Ráadásul az átállás kapcsán számos olyan probléma merülhet fel, amely alapvetően fenntartói kompetencia: megfelelö eszközök és internetkapcsolat biztosítása, általánosan használható digitális tananyag fejlesztése, elérhetősége, stb.

A válaszok alapján mégis egyértelmü, hogy nem a fenntartótól vagy az oktatásirányító minisztériumtól, esetleg annak intézményeitől kaptak segítséget az érintettek, hanem elsősorban egymástól (9. ábra). Fontosak voltak az iskolán túli szakmai kapcsolatok is az átállással összefüggő kihívásokkal való megküzdésben. A tanárok fele jelezte, hogy az igazgatótól kapott segítséget, de a legkevésbé a fenntartó támogatta a tanárokat a nehézségekkel való megküzdésben (átlagosan $18 \%$ jelölte ezt). A válaszokban elhanyagolható különbség volt aszerint, hogy mekkora az iskolában a HHH-arány, ami alól csak a fenntartótól kapott támogatás volt kivétel: a hátrányos helyzetủeket oktató iskolák tanárai közel kétszeres arányban jelezték, hogy kaptak közvetlen segítséget a fenntartóiktól.

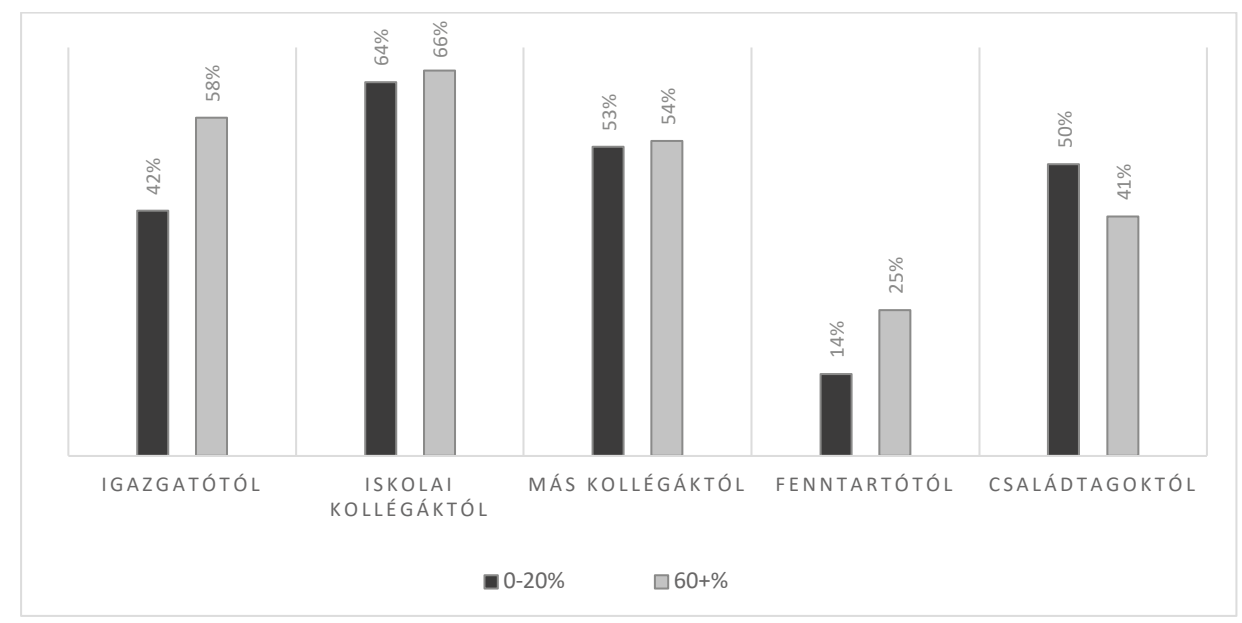

9. ábra. A digitális oktatás kapcsán kínált segitség megitélése az alacsony HHH-arányú és szegregált iskolák pedagógusai körében

A legtöbb válaszadónak a digitális oktatás kapcsán a legnagyobb nehézsége a helyzet váratlansága miatt adódott, valamint, hogy a hagyományos tananyagot nehéz volt hirtelen online módon megtanítani. Ezt úgy foglalta össze az egyik válaszadó, hogy „,eszköztelenség, idő, platformok, digitális tanmenet, kidolgozott bejáratott módszerek hiánya" 
jellemzi az átállást, és hogy „semmiféle feltétel és egységes szakmai segítség nélkül kell kitaláljuk és felépítsük a rendszert, miközben a fenntartó csak statisztikai jelentéseket követel".

\section{Ez egy más állapot?}

A válaszadók túlnyomó többsége egyetértett azzal, hogy nem lehet ugyanazokat az elvárásokat közvetíteni a tanulók felé, mint korábban. Például szinte senki nem tervez buktatást az év végén. Ugyanakkor a válaszadók véleménye abban már megoszlott, hogy naponta kell-e feladatokat adni, vagy elég ritkábban, továbbá, hogy fontos-e ebben a helyzetben a tananyaggal való haladás, vagy ezt is el lehet most engedni.

„Tudom, hogy hiába küldöm el az internetes linkeket a gyerekeknek, nem biztos, hogy meg tudják nézni, képesek azok alapján ismeretet elsajátítani. Mindent úgy le kell írnom nekik, ahogy órán, szóban tanítok. Ez nagyon sok munka!"

Sokan saját személyes érzéseiket írták le, egyrészt annak kapcsán, hogy hiányzik számukra a személyes találkozás; másrészt, hogy megnövekedett a leterheltségük. Arra is rákérdeztünk, hogy mit tart pozitív fejleménynek az átállás kapcsán, amire a legtöbben a digitális kompetenciáik és a rugalmasságuk, valamint a pedagógusok közötti szolidaritás megerősödését írták. Többen válaszolták azt is, hogy a bekapcsolódott $\mathrm{HHH} /$ roma gyerekek sokkal motiváltabbá váltak, és a szüleikkel való együttmüködés is megerősödött.

„Sokat javult a gyerekek hozzáállása a tanuláshoz, ezzel együtt megnőtt a felelősségvállalásuk, az egyéni bánásmód jobban érvényesíthető, a kölcsönös egymásrautaltság mélyebb emberismeretet eredményez. Javul a szövegértés, a kitartás, az elmélyült, önálló munka, az időbeosztás. A szülők többet foglalkoznak a gyermekeikkel. A tananyagban, a fejlesztésben előtérbe kerülhetnek az igazán fontos és fejlesztő, az életkori sajátosságokhoz illeszkedő, inspiráló feladatok."

Végül rákérdeztünk arra is, hogy milyen javaslatai lennének azzal kapcsolatban, hogy a digitális tanrend sikerrel müködjön a $\mathrm{HHH} /$ roma gyerekek körében. A válaszadók fele az infrastruktúra biztosítását tartotta a legfontosabbnak, de több mint negyedük tartotta lényegesnek azt is, hogy a pedagógusoknak rugalmasan kell alkalmazkodniuk a kialakult helyzethez. Itt gyakran előkerültek a családok megváltoztatásának fontosságát hangsúlyozó megjegyzések. Sokan inkább a család felelősségét látták abban, hogy nem, vagy sikertelenül zajlott a digitális oktatásra való átállás.

„A gyerekek motiválatlanok, a családjuk sem támogatja ebben őket eléggé, sokszor nem reagálnak a megkereséseimre."

„[A]zon tanulók hozzáállása, akik a hagyományos tanrendben sem tettek semmilyen erőfeszítést, nem dolgoztak, most sem engedik meg, hogy bevonjuk őket a munkába. például elbújnak." 


\section{Konklúzió}

Írásunkban egy olyan kutatás eredményeit mutattuk be, amelyet az oktatás digitális átállását követően nagyon rövid időn - egy hónapon - belül készítettünk hátrányos helyzetü és roma gyerekeket oktató iskolák pedagógusainak körében. Feltételezéseinknek megfelelően a hátrányos helyzetü tanulók nagyobb arányban maradtak ki a digitális oktatásból. A megfelelő tanulási tér és az önálló tanuláshoz szükséges képességek hiányát az internetelérés és az IKT- eszközök hiánynál is nagyobb arányban említették problémaként a pedagógusok. A kistelepülésen élő hátrányos helyzetü és roma tanulók helyzete tünik a leginkább aggasztónak, ami vélhetően jelentősen összefügg az internetelérés és közlekedés nehézségeivel. Kutatásunk arra is rámutat, hogy még ahol nem is szakadt meg a kapcsolat az iskola és a tanulók között, az iskola által kínált szolgáltatások a HHH tanulók esetében ott is szegényesebbek, illetve szülői segítség hiányában vélhetően nem tudják kiaknázni azok fejlesztő hatását. A családok és az iskola kapcsolattartási mintázataiban is eltéréseket azonosítottunk, ami arra is felhívja a figyelmet, hogy a digitális oktatás során nemcsak a hátrányos helyzetü tanulók, de szüleik esetében is többletsegítségre van szükség.

Kutatásunk eredményei alapján elég nagy biztonsággal prognosztizálhatjuk, hogy a digitális oktatásra való kényszerü átállás tovább növelte az oktatási egyenlőtlenségeket Magyarországon. Ez más országokban is látható jelenség, azonban Magyarországon a hátrányos helyzetü gyermekeket oktató iskolák tanárainak nyújtott kormányzati, fenntartói támogatás szinte teljes hiánya, valamint a hátrányos helyzetü gyerekek és családjaik magára hagyása miatt azt valószínüsíthetjük, hogy az oktatási egyenlőtlenségek növekedése különösen erős lesz. Véleményünk szerint a jövőben jelentős növekedés várható az évismétlő és az oktatásból kihulló gyermekek számában. Különösen igaz lehet ez a középiskolás korú hátrányos helyzetü diákokra nézve: ők már közel egy éve távoktatásban tanulnak úgy, hogy jelentős részük számára az otthoni körülményeik ezt alig teszik lehetővé, és az otthoni tanuláshoz szükséges infrastruktúra sem áll rendelkezésükre. A hátrányos helyzetű és roma fiatalok jellemzően szakképző iskolába járnak, ahol gyakorlati oktatásban kell(ene) részt venniük. Könnyen belátható, hogy ez távoktatásban a többi középfokú iskolatípushoz (gimnázium, technikum) viszonyítva még nehezebb; egyes területeken egyenesen lehetetlennek tünik. Az általános iskolai tanulók esetében is minden bizonnyal tovább nyílik az oktatás társadalmi ollója, hiszen kutatásunk rámutat arra, hogy minél magasabb a hátrányos helyzetü tanulók aránya, annál több tanuló nem tudott bekapcsolódni a digitális oktatásba és szakadt meg a tanárokkal a kapcsolata (vagyis estek ki már az első hónap során az oktatásból). Akikkel nem szakadt meg a kapcsolat, azok között is nagyon jelentős arányban vannak, akik számára papíron megküldött tananyagok és feladatok jelentették a 'távoktatást'. Egy olyan családban, ahol a szülők maguk is iskolázatlanok, nehéz egzisztenciális körülmények között élnek, ahol a lakhatási szegénység jellemző, nyilvánvaló, hogy az ilyenformán formálisan fenntartott iskola tartalmilag, tudáselsajátítás szempontjából vajmi kevés hozadékkal bír. A pedagógusok döntő többsége szerint a szülök jelentős segítsége nélkül lehetetlen volt az oktatás, és az egyik legnagyobb nehézségnek azt tartották, hogy a tanulók nem tudták önállóan értelmezni a feladatokat és tanulnivalót. Ezen adatok alapján nyilvánvaló, hogy a hátrányos helyzetü tanulók lemaradása tovább növekedett a digitális oktatás idején, még akkor is, ha be tudtak kapcsolódni az oktatásba.

A kutatást nem tudtuk folytatni, így a digitális oktatás 2019/20 tavaszi félévének egészéről nincsenek adataink, ugyanúgy, mint ahogy arról sem, hogy milyen mélyebb lenyomatot hagyott az oktatás az abban részt vevő diákok tanulmányaiban. Ilyen következtetésekre sajnos az elérhető statisztikák sem adnak lehetőséget, hiszen az oktatás 
legfontosabb kapcsolódó mutatói, úgymint az évismétlések száma, vagy az oktatásból idő előtt kihullott gyerekek száma, még nem elérhetőek a kutatók számára. A helyzet még aggasztóbb, ha figyelembe vesszük, hogy a 2020 április eleji pillanatfelvétel egy elhúzódó állapot kezdete volt: a járvány még írásunk megjelenésekor sem tünt el, és bár az általános iskolák nyitva maradtak (sok-sok kényszerszünettel, tanári és tanulói hiányzással), a középiskolai oktatás a 2020-as őszi szünetet követően újra digitális oktatásra állt át. Vagyis, a középiskolai diákok két hónap kivételével írásunk megjelenésekor már közel egy éve online oktatásban vesznek részt úgy, hogy nem ismertek sem a személyiségükre, sem az iskolai elörehaladásukra vonatkozó alapvető információk. Mindenképp fontos kutatási feladat a járvány és az azt követő online oktatás hatásának vizsgálata a szakképzésben (szakképző iskola, technikum) tanulókra vonatkozóan. Kutatásunk több olyan sajátosságra hívja fel a figyelmet, amely hosszabb távon is befolyásolja az oktatásban részt vevők esélyeit és lehetőségeit.

Végül ismét hangsúlyozzuk, hogy e kutatás nem reprezentatív, és az oktatási digitális átállásának egy korai időpontjában készült pillanatfelvétel. Emiatt mind a technikai feltételek és IKT kompetenciák szempontjából, mind az oktatásból kieső diákok aránya tekintetében nem lehet pontosan tudni milyen irányú változások következtek be az adatfelvételt követően. Emellett az általánosíthatóságot tekintve további korlát, hogy feltételezhetően a kérdőívet nagyobb arányban töltötték ki olyan pedagógusok, akik felkészültebbek és motiváltabbak a digitális oktatás megvalósításában (pl. online fórumok résztvevői), így valószínü, hogy a valóságosnál kedvezőbb helyzetet mutatnak az adatok. Az idő és források hiánya miatt nem volt lehetőségünk szisztematikusan feltárni a digitális oktatásban részt vevő hátrányos helyzetü diákok és családjaik tapasztalatait, ami vélhetően számos ponton kiegészítené, árnyalná a felvázolt képet.
Végül ismét hangsúlyozzuk, hogy e kutatás nem reprezentatív, és az oktatási digitális átállásának egy korai idópontjában készült pillanatfelvétel. Valószinúsithetó, hogy mind a technikai feltételek és IKT komaz oktatásból kiesó diákok aránya tekinttében pozitív irányú változások következtek be az adatfelvételt követốn. Emellett az általánosithatóságot tekintve további korlát, hogy feltételezhetöen a kérdôivet nagyobb arányban töltötték ki olyan pedagógusok, akik felkészültebbek és motiváltabbak a digitális oktatás megvalósitásában (pl. online fórumok résztvevói), igy valószinú, hogy a valóságosnál kedvezóbb helyzetet mutatnak az adatok. Az idố és források hiánya miatt nem volt lehetôségünk szisztematikusan feltárni a digitális oktatásban részt vevó hátrányos helyzetú diákok és családjaik tapasztalatait, ami vélhetốn számos ponton kiegészitené, árnyalná a felvázolt képet. petenciák szempontjából, mind 


\section{Köszönetnyilvánítás, támogatás}

A kutatás a Foundation Open Society Institute támogatásának köszönhetően valósult meg (Grant Number OR2019-65252). Köszönjük a kérdőívet kitöltő pedagógusoknak részvételüket, külön megköszönve a nyitott kérdésekre adott részletes válaszaikat. Köszönjük továbbá az interjúalanyok részvételét. Külön köszönetet szeretnénk mondani Szücs Norbertnek (SZTE, Motiváció Oktatási Egyesület) az írás elkészítésében nyújtott segítségért, Bernáth Gábornak és Árendás Zsuzsannának (Társadalomtudományi Kutatóközpont) az elkészített interjúkért, valamint Ságvári Bencének (Társadalomtudományi Kutatóközpont) a térképek elkészítéséért.

\section{Irodalom}

Andrew, A., Cattan, S., Costa Dias, M., Farquharson, C., Kraftman, L., Krutikova, S., Phimister, A. \& Sevilla, A. (2020). Inequalities in Children's Experiences of Home Learning during the COVID-19 Lockdown in England. Fiscal Studies, 41(3), 653-683. DOI: 10.1111/1475-5890.12240

Bacher-Hicks, A., Goodman, J. \& Mulhern, C. (2021). Inequality in Household Adaptation to Schooling Shocks: Covid-Induced Online Learning Engagement in Real Time. Journal of Public Economics, 193. DOI: 10.1016/j.jpubeco.2020.104345

Bradley, R. H. \& Corwyn, R. F. (2020). Socioeconomic status and child development. Annual Review of Psychology, 53(1), 371-399. DOI: 10.1146/ annurev.psych.53.100901.135233

Chetty, R., Friedman, J. N., Hendren, N., Stepner, M. \& Opportunity Insights Team (2020). The economic impacts of COVID-19: evidence from a new public database built using private sector data. https:// opportunityinsights.org/wp-content/uploads/2020/05/ tracker_paper.pdf DOI: 10.3386/w27431

Cooper, H., Nye, B., Charlton, K., Lindsay, J. \& Greathouse, S. (1996). The effects of summer vacation on achievement test scores: A narrative and meta-analytic review. Review of Educational Research, 66(3), 227-268. DOI: 10.3102/00346543066003227

Daniel, J. (2020). Education and the COVID-19 pandemic. Prospects, 49(1), 91-96. DOI: 10.1007/ s11125-020-09464-3

DESI (2019). Digital Economy and Society Index (DESI) 2019. Country Report Hungary. European Commission. https://ec.europa.eu/newsroom/dae/document.cfm?doc_id $=59898$

EMMI (2020). Új munkarend a köznevelési és szakképzési intézményekben (2020. március 14.). https:// koronavirus.gov.hu/cikkek/emmi-uj-munkarend-koznevelesi-es-szakkepzesi-intezmenyekben

Fana, M., Torrejón Pérez, S. \& Fernández-Macías, E. (2020). Employment impact of Covid-19 crisis: from short term effects to long terms prospects. Journal of
Industrial and Business Economics, 47(3), 391-410. DOI: $10.1007 / \mathrm{s} 40812-020-00168-5$

Fejes József Balázs, Tóth Edit \& Szabó Dóra Fanni (2020). Az oktatási méltányosság és aktuális kérdései Magyarországon. Magyar Tudomány, 181(1), 68-78. DOI: 10.1556/2065.181.2020.1.7

Fejes, J. B. (2012). Learning motivation of disadvantaged students. In Seel, N. M. (szerk.), Encyclopedia of the Sciences of Learning. Springer. 1935-1937. DOI: 10.1007/978-1-4419-1428-6_680

Fekete Mariann (2020). Digitális átállás - az első hét tapasztalatai. Iskolakultúra, 30(9), 77-95. DOI: 10.14232/iskkult.2020.9.77

Fekete Tamás \& Porkoláb Ádám (2020). Karanténpedagógia a magyar közoktatásban. Iskolakultúra, 30(9), 96-112. DOI: 10.14232/iskkult.2020.9.96

Fodor Éva, Gregor Anikó, Koltai Júlia \& Kováts Eszter (2020). Az egyenlőtlenségek alakulása a koronajárvány idején Magyarországon. FriedrichEbert-Stiftung. http://library.fes.de/pdf-files/bueros/ budapest/16606.pdf

Grewenig, E., Lergetporer, P., Werner, K., Woessmann, L. \& Zierow, L. (2020). Covid-19 and Educational Inequality: How School Closures Affect Low- and High-Achieving Students. IZA Discussion Paper No. 13820.

Gyetvai Viktor (2020). Felmérés a 2020-as távoktatásról. Alapítvány a Diákközpontú Oktatásért. https:// diakparlament.hu/wp/wordpress/wp-content/uploads/2020/11/Felmeres-a-tavoktatasrol_ADOM-Diakmozgalom.pdf

Hajdu Tamás, Hermann Zoltán, Horn Dániel \& Varga Júlia (2019). A közoktatás indikátorrendszere 2019. Közgazdaság- és Regionális Tudományi Kutatóközpont, Közgazdaság-tudományi Intézet.

Havas Gábor \& Liskó Ilona (2005). Szegregáció a roma tanulók általános iskolai oktatásában. Felsőoktatási Kutatóintézet. 
Havas Gábor (2008). Esélyegyenlőség, deszegregáció. In Fazekas Károly, Köllő János \& Varga Júlia (szerk.), Zöld könyv a magyar közoktatás megújításáért. Ecostat. 121-138.

Heckman, J. J., Humphries, J. E., Urzua, S. \& Veramendi, G. (2011). The Effects of Educational Choices on Labor Market, Health, and Social Outcomes. Working Papers 2011-002. Human Capital and Economic Opportunity Working Group, http://humcap.uchicago.edu/RePEc/hka/wpaper/HHUV_2010_ effect-edu-choice.pdf

Hermann Zoltán (2020). Hány diákhoz nem jut el az online távoktatás? Közgazdaság- és Regionális Tudományi Kutatóközpont, Közgazdaság-tudományi Intézet. https://www.mtakti.hu/koronavirus/hany-diakhoz-nem-jut-el-az-online-tavoktatas/12769/

Ipsos (2020). A digitális oktatás infrastrukturális háttere és megvalósithatósága Magyarországon. https://www.ipsos.com/hu-hu/digitalis-oktatas-infrastrukturalis-hattere-es-megvalosithatosaga-magyarorszagon

Kende, Á. \& Szalai, J. (2018). Pathways to early school leaving in Hungary Ethnicised inequalities in education and the case of Roma youth. In: Van Praag, L., Nouwen, W., Van Caudenberg, R., Clycq, N. \& Timmerman, C. (szerk.), Comparative Perspectives on Early School Leaving in the European Union. Routledge. 31-44.

Kertesi, G. \& Kézdi, G. (2016). On the Test Score Gap between Roma and non-Roma Students in Hungary and its Potential Causes. Economics of Transition, 24(1), 135-162. DOI: 10.1111/ecot.12076

Kóródi Kitti, Jagodics Balázs \& Szabó Éva (2020). Az észlelt tanári énhatékonyságot befolyásoló tényezők vizsgálata a kényszerủ digitális oktatás időszakában (1. rész). Iskolakultúra, 30(10), 38-52. DOI: 10.14232/iskkult.2020.10.38

Köllő János (2020). Foglalkoztatás a koronavírus-járvány első hullámának idején. In Fazekas Károly, Elek Péter \& Hajdú Tamás (szerk.), Munkaeröpiaci Tükör 2019. KRTK KTI.

KSH (2020). Magyarország, 2019. Központi Statisztikai Hivatal. https://www.ksh.hu/docs/hun/xftp/ idoszaki/mo/mo_2019.pdf

L. Ritók Nóra (2020). Ahol nincs fogadókészség. Osztályfönökök Országos Szakmai Egyesülete. https:// osztalyfonok.hu/2174/

McNulty, R. \& Baird, K. (2020). The impact of school closures on student learning: An analysis of real-time data for 1.6 million students using Achieve3000 literacy. Achieve 3000 .

Messing, V. \& Bereményi, Á. (2017). Is ethnicity a meaningful category of employment policies for Roma? A comparative case study of Hungary and Spain. Ethnic and Racial Studies, 40(10), 1623-1642. DOI: 10.1080/01419870.2016.1213402

Messing, V. (2014). Methodological puzzles of surveying Roma/Gypsy populations. Ethnicities, 14(6), 811-829. DOI: 10.1177/1468796814542180

Messing, V. (2017). Differentiation in the making: Consequences of school segregation of Roma in the Czech Republic, Hungary, and Slovakia. European Education, 49(1), 89-103. DOI: 10.1080/10564934.2017.1280336

Molnár Gyöngyvér, Hódi Ágnes, Ökördi Réka \& Mokri Dóra (megjelenés alatt). A digitális oktatás hatása 2-8. évfolyamos diákok tudás- és képességszintjére az olvasás-szövegértés, a matematika és természettudományok területén. Iskolakultúra.

OECD (2015). Students, Computers and Learning. Making the Connection. OECD Publishing. DOI: 10.1787/9789264239555-en

OECD (2019). TALIS 2018 Results (Volume I): Teachers and School Leaders as Lifelong Learners. OECD Publishing.

Papp Z. Attila (2011). A roma tanulók aránya Magyarországon és a tanulói teljesítmények az általános iskolai oktatásban. In Bárdi Nándor \& Tóth Ágnes (szerk.), Asszimiláció, integráció, szegregáció: párhuzamos értelmezések és modellek a kisebbségkutatásban. Argumentum. 224-267.

Radó, P. (2020). Social selection in education: the wider context of the segregation of Roma pupils in Hungary. CPS Working Paper Series, Vol. 4. https:// cps.ceu.edu/sites/cps.ceu.edu/files/attachment/publication/3258/cps-working-paper-educ-social-selection-education-hungary-2020.pdf

Szűcs Norbert \& Kelemen Valéria (2013). A szegedi deszegregációs intézkedés: egy gettóiskola megszüntetése. In Fejes József Balázs \& Szücs Norbert (szerk.), A szegedi és hódmezövásárhelyi deszegregációt támogató Hallgatói Mentorprogram. Öt év tapasztalatai. Belvedere Meridionale. 36-57. DOI: 10.14232/belvbook.2013.58504.b

Zolnay János (2007). Nyilvánvaló és közvetlen veszély. In Törzsök Erika, Paskó Ildi \& Zolnay János (szerk.), Cigánynak lenni Magyarországon. Jelentés 2007. A gyülölet célkeresztjében. Európai Összehasonlító Kisebbségkutatások Közalapítvány. 255-263. 


\section{Jegyzetek}

${ }^{1} \mathrm{Az}$ eredményekről több portál is beszámolt, például: https://444.hu/2020/04/28/egy-szobaban-tobben-elnek-pici-babatol-a-nagymamaig-se-hely-se-lehetosega-tanulasra https://index.hu/belfold/2020/04/28/digitalis_atallas_oktatas_szegregalt_hatranyos_helyzet_kutatas/ https:/qubit.hu/2020/05/12/igy-tunnek-el-a-magyar-kozoktatasbol-a-hatranyos-helyzetu-es-roma-gyerekek-a-jarvany-idejen

2 1997. évi XXXI. törvény a gyermekek védelméröl és a gyámügyi igazgatásról, 67/A. §

${ }^{3}$ A felhívás így szólt „Hátrányos helyzetű és/vagy roma gyerekeket tanító pedagógusok tapasztalatai és véleménye a digitális tanrendü oktatásra való átállásról. Az alábbi kérdőív segítségével szeretnénk feltérképezni, hogy azok a pedagógusok, akik a leghátrányosabb helyzetü tanulókat tanítják, miként élték meg az elmúlt hetek átállását, milyen segítséget kaptak kollégáiktól, az igazgatójuktól és a fenntartójuktól. Továbbá kíváncsiak vagyunk a véleményére a tanulók tanításával kapcsolatban, valamint arra, hogy miként tudnak ebben a helyzetben a szülőkkel együttmüködni. A kérdőív anonim és kb. 10 percet vesz igénybe."

${ }^{4}$ A segítő civil szervezetek körében készített felmérést Bernáth Gábor vezette a Partners Hungary kapcsolódó kutatásának keretében.

${ }^{5}$ https://24.hu/tech/2020/03/16/kinek-jar-ingyen-mobilnet-koronavirus-telekom-teleno-vodafoneszolgalatok-digi/

\section{Absztrakt}

A koronavírus terjedésének megállítása érdekében bevezetett digitális oktatás vélhetően számos akadályba ütközött a hátrányos helyzetű tanulók esetében. Ugyanakkor ennek részleteiről hazai viszonylatba még alig rendelkezünk információkkal. Kutatásunk célja az volt, hogy a hátrányos helyzetű tanulók célcsoportjára fókuszálva 2020 tavaszán feltárjuk a digitális oktatás első hónapjának tapasztalatait. Elemzésünk alapja egy online kérdőív, amelyet 425 pedagógus töltött ki. A kérdőíven alapuló elemzést iskolaigazgatókkal és roma, vagy roma közösségeket támogató civilszervezetek vezetőivel készült interjúk egészítik ki. Feltételezéseinknek megfelelően a hátrányos helyzetű tanulók nagyobb arányban maradtak ki a digitális oktatásból. A megfelelő tanulási tér és az önálló tanuláshoz szükséges képességek hiányát az internetelérés és az IKT-eszközök hiánynál is nagyobb arányban említették akadályként a pedagógusok. A kistelepülésen élő hátrányos helyzetủ és roma tanulók helyzete különösen aggasztónak tűnik. Amennyiben nem szakadt meg a kapcsolat az iskola és a tanuló között, a digitális oktatás a fenti okok miatt akkor sem valósult meg; a hátrányos helyzetű tanulók gyakran csupán papíron, heti rendszerességgel kaptak tanulnivalót és feladatokat. Szülői segítség nélkül vélhetően nem tudtak megfelelően tanulni, fejlődni ebben az időszakban. Eredményeink alapján az online oktatás következményeként az oktatási egyenlőtlenségek növekedése prognosztizálható hazánkban. 